\title{
Biological Ramifications of the Subseabed Disposal of High-Level Nuclear Waste
}

Leo S. Gomez, R. R. Hessler, D. W. Jackson, Melvin G. Marietta,

7f K. L. Smith, Jr., Daniel M. Talbert, A. A. Yayanos

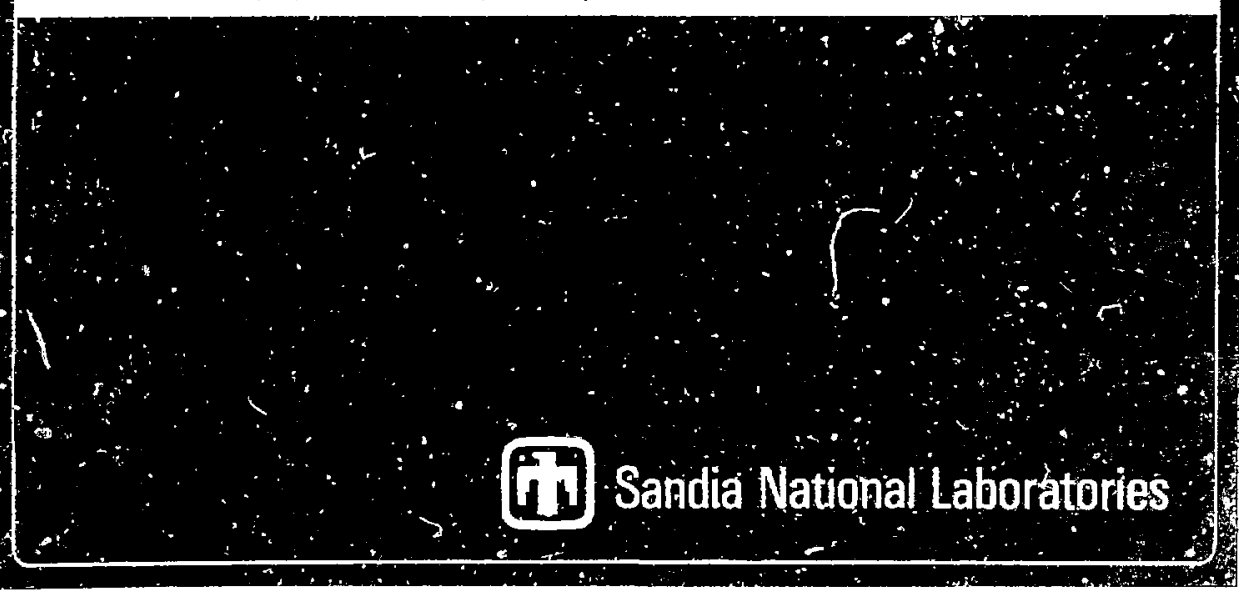


Biological Ramifications of the Subseabec Disposal

of High-level Nuclear Waste

L. S. Gamez, R. R. Hessler, D. W. Jackson, M. G. Naxietta,

K. L. Smith, Jr., D. M. Talbert, A. A. Yayanos

\begin{abstract}
The primary goal of the U.S. Subseabed Disposal Frogram (SLF) is to assess the technical and envirurmental feasibility of Jisposing of high-level nuclear waste in deep-sea seciments. The subseabec biology program is chargeo with assessing possible ecosystem effects of radicnuclides as well as possible health effects to man from radicnuclides which may be released in the deep sea and transported to the coean surface. Current biological investigations are attempting to determise benthic community structure; benthic commity metabolism; the biology of deep-sea mobile scavengers; the faunal composition of midwater nekton; rates of microbial processes; ano the rajiation sensitivity of cep-sea organisms. Existing mooels of the oispe:sal of radicnuclides in the deep sea have not considered many of the possible biological mechanisms wich may influence the moverrent $c:$ raoicnuclides. Therefore, a multi-compartment foctheb model is being deveioped which considers both biological and physical influences on racioruciioe transport. This model will allow parametric studies to be mace of the impact on the ccean enviroment and on man of potentjai releases of radionuciides.
\end{abstract}

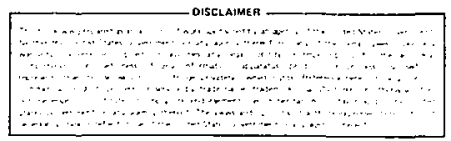


Subseabed Biology Team:

L. S. Gomez, M. G. Marietta, D. M. Talbert:

Sandia Laborator ies

Albuquerque, N S/lgs

R. R. Hessler, K. L. Smith, Jr., A. A. Yayanos:

University of California

Scripps Irsititution of Dceanography

La Jolla, CA 92093

D. W. Jackson:

Falcon Research anò Develusment

2350 Alamo Avenue SE

Albuquerque, NM 37106 


\section{Contents}

Page

Introduction $\ldots \ldots \ldots \ldots \ldots \ldots \ldots \ldots \ldots \ldots \ldots \ldots \ldots \ldots \ldots \ldots \ldots \ldots$

Marine Trophic structure $\ldots \ldots \ldots \ldots \ldots \ldots \ldots \ldots \ldots \ldots \ldots \ldots \ldots \ldots \ldots .2$

Nuclice Migration Model Development ..................... 5

Mass Density Parameters ............................ 7

Transport Farameters .............................. ?

SDP Eiology Program $\ldots \ldots \ldots \ldots \ldots \ldots \ldots \ldots \ldots \ldots \ldots \ldots \ldots \ldots \ldots \ldots$

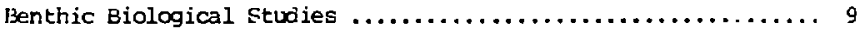

Water column studies $\ldots \ldots \ldots \ldots \ldots \ldots \ldots \ldots \ldots \ldots \ldots \ldots \ldots \ldots \ldots$. 12

Faciaticn Biology studies $\ldots \ldots \ldots \ldots \ldots \ldots \ldots \ldots \ldots \ldots \ldots \ldots$

Firall Caments $\ldots \ldots \ldots \ldots \ldots \ldots \ldots \ldots \ldots \ldots \ldots \ldots \ldots \ldots \ldots \ldots \ldots \ldots, 18$

Figures

1. Fef esentative Marim siota $\ldots \ldots \ldots \ldots \ldots \ldots \ldots \ldots \ldots \ldots \ldots$

2. Nuclide Migration Model $\ldots \ldots \ldots \ldots \ldots \ldots \ldots \ldots \ldots \ldots \ldots \ldots \ldots, 21$

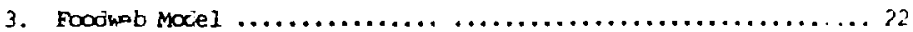




\section{Biological Ramifications of the Subseabed Dispol of High-level Nuclear Waste}

\section{Introduction}

Development of a :atisfactory method of oisposing of high-level nuclear wastes is a prerequisite to decioing whether or not nuclear power should be relied upon as a major energy source. At present several land disposal options are being investigateo by the U.S. Department of Energy (DOE) (McElroy and Burns, 2979). In addition, a program was begun in 2973 by the DOE (then the Atcnic Energy Comission) to assess the feasibility of using geologic formations beneath the wor: $=$ coeans for the disposal of appropriately packagec and solioified high-level nucisar wastes. The U.S. Subseabeo Disposal Program (SDP) is currently conducting research in the areas of site selection, multiple barrier icentification, waste canister emplacement techniques, high-level nuclear waste transportation, socio-political aspects, risk/safety analyses, econcmics, and environmental impact. The subseaber bioiogy program, which is to contribute to an environmental impact evaluation, is chargeo with assessing possible ecosystem effects and human health effects from raoionuclioges which may be releasec in the deep sea and transpor ted through the water column to the ocean surface.

In order to evaluate the feasibility of subseaved nuclear waste disposal, it is necessary to consider the results of leakage or accidental failure to emplace the nuclear waste canister within the deep-sea sediments. Accidental release is possible for any nuclear waste disposal option, and the risks associateo with each option must be evaluated so that comparisons among options can be inade. Therefore, it 
is recessary to be able to understand the migration of escaped radionuclides from the canister emplacoment site within the sediments (or possibly elsewhere for various accicents) through the sediments, water column and ecosystem to man. Only in $t^{i}$. way can the environmental impact of subseabeơ nuclear waste òisposal be quantitatively evaluated.

Present studies focus on the abyssal hill regions of the deep sea floors in the middle of tectonic plates anò under the major surface current gyres. Anderson (1979) discusses the characteristics used to select generic study sites.

\section{Mas ine Trophic Structure}

The marine biomass of the worlo oceans has been estimateo at 10 Lillion tons (Nenzies et al., 1973). Over half of this 16.7 billion $t$ uns) can be assigned to the bentros. About 5.5 billion tons are distributed in the shoal waters of the continental shelves, and only 56 million tons remain on the abyssal sea floor at depths greate: than 3000 meters. Thus, these depths generally have a low bicmass camparable to that of terrestrial deserts. Nevertheless, representatives of many of the groups of organisms which are cammonly found in shallow seas are also found in the deep sea (Hessler, 1974). Figure $I$ is a simplified spatial frame of reference for the ocean with same representative marine organisms.

If the deep sea is definea as starting at a depth of 1000 meters, it represents about three quarters of the biosphere (Jannasch, 1978). In the deep sea there is no light (other than bioluminescence) and the 
temperature is a few degrees above zero degrees Celsius. Hydrostatic pressure increases by about one atmosphere with every 10 meters of depth. For all organisns in the deep sea nutrition becames a most important problem.

Primary production in the euthotic region (the upper 200 meters) of the coean is a principal source of food (the most limiting resource) for deep-sea henthic communities (Dayton and Hessler, 1972). In the waters of the central gyres such primary production is low (Hessler and Junars, 2977). Furthermore, nutrients from land runoff are insignificant because the mid-gyres are remote frcm land, and because of prevailing coanic currents. Great water depth canbines with these other factors to maintain a lower nutrient supply to the deep ovan bottom. than at any other place in the ocean (Hessler and Jumar:, 1977). As a result, high species diversity and low standing crop are characteristics of deep-sea faunas (Sanders and Hessler, 1969).

At present, the rates at which essential nutrients are recyclec in the benthos are largely unknown, as are the rates of growth, metabolism, and reprocuction of deep-sea crganisms (Jannasih, 1978). There are also few data available on population densities, food webs or vertical and horizontal migrations with which to evaluate radionuclioe uptake, accumllation, and transport through the deep-sea ecosystem. Because deep benthic communities are the first that would be exposed to released radionuclices, much of the research in the subseabed biology program has focused on deep-sea ecology.

The influence of biological pathways on the potential trarsport of radionuclides iram the deep-sea seciments to the ocean surface is of 
prime importance (Hessler and Jumars, 1979). The infauna in a benthic cammunity could mediate radionuclide transport by moving seäiment and by moving pore water in and out of the sediments. Roving megafauna may also contribute to bioturbation. Radianuclides that would otinerwise remain sorbec on chep-sea sediments may then be transported by currents to areas of low radionuclide concentration. Feeding and excretion can transfer radionuclides through the seas. since coprophagy, the ingestion of feces, is an important nutritional source in a wide range of marine animals (Frankenberg and Smith, 1967), it may he an important :actor in the transfer of radionuclides that have been brought into surface waters. Sore benthic invertebrates have pelagic eggs or larvae that may disperse horizcitally. This mode of reproduction, which is a usual breeding pattern among shallow water marine camounities (Nenzies et al., 1973) may contribute to radjonuclide transport. Vertical migrations in the water column may range from a diel pattern over hundreds of meters (Longhurst, 1976) to the ontogenetic migrations of rattail fish that can extend a few thousand aters up from the bottom (Merrett, 1978). Marine mammals and birds may also transport radionuclides by their annual horizantal migrations of thousands or miles. Many species of fish of commercial interest to man have ararratic anadromous migrations. Some zommercial fish reproduce with pelagic eggs which may be transported horizontally for many miles (Russell, 1976). These and other biological interactions are influenced by an assortment of physical processes such as wind-driven currents, edäies, upwellings and thermahaline circulacion. All are potentiaily inportant in radicnucliòe transport. 


\section{Muclide Migration Nodel Develogment}

En isting models of the dispersal of radionuclides in the deep sea have not considered many of the possible biological mechanisms which may influence the movement of such radionuclides. Therefore, a multi-compartment model is being developed that consicers both biological and physical influences on radionuclide transport. This model will allow parametric studies to be mace of the impact on the environment and on man of potential releases of radionuclides into the sea. This paper will concentrate on the biological influences of foodheb model development with minimal consideration of the physical influences.

The nuclide migration model is directeo towards answering two questions. What is the effect of radionuclides which may be released in the defp sea upon the marine envirorment, ano what is the effect of such a release upon man? These questions require an ability to predict the levels of radioactivity in the marine biota and the ultinate raciation dose to man.

The present model (Fig. 2) is made up of several mociules: near-field transpurt with heat effects, far-field transport through the seoiments, water column and biological transport, human dosimetry, affecteo human populations and human health effects.

The marine ecosystem has been compartmentalized after a scheme reported by Wishner (1977) for the SDP biology program. A compartment represents a functional grouping of many species in the biota. The species within a compartment are assumed to behave similarly in their 
relationships with the enviroment as well as in the ways chey may transpert radionuclides. Group bounds on the standing crop and ratabolic rates may then be assigned to each campartment by considering characteristics of the group. The benthic boundary layer model (s) extends from the lower limit of biological activity in the seciments through the lower 20-50 meters of the water column. Above the benthic boundary layer are one or more midwater models. The uppor part of the water colum (euphotic zone) is represented by another model. These models are shown schematically in Fig. 3.

Transport between biological compartments and physical ccoldztments is complex. Radianuclides may be transported by prejator-prey interactions, excretion, mortality, adsorption, migration, reproduction and molting. In addition, seöiments (organic anä imorganic) anó particulate materials may be consumed. Radionuclides may also he taken up directly from the water column and from interstitial water. Various transport mechanisms must be considered, such as, association-dissociation in the seciments and water column, erosicn-sedimentation, vertical and horizontal water dispersion, bioturbation, horizontal migration of $l$ enthic megafauna, vertical migration of midwater organisms, and the dispersion of host particulate matter. These forms of radionuclide transperts, which are depicted as arrows between the boxes in Fig. 3, are being or will be carefully examined.

In order to develop a realistic da'a base with which to exercise the model, deep ano shallow-water biological data have been compiled from the literature. In addition, algorithms for computing transfer rates 
between compartments have been developed (Jackson, 1979).

The compilation of model input data is described very briefly below.

a) Mass Density Parameters:

Mass density is defined in the mojel as kilograms wet weight mass per square or cubic meter of sediment-water interface or water volume. respectively. The mass density of organisms (bicmass) is compilec fron: the literature in several forms: direct biomass determinatior's, direct counts of organisms with an estimate of mean individual weiuht, direct measurement of a bicchemical parameter (pigmints, adenosine triphosphate, etc.) coupled with appropriate corversion fiactors, ane indirect estinate of the bicmass density in one compartment baseo or a direct measurement of density in another, e.g., in ore stuơy "the mass of herbivorous and amnivorous zooplankton is appraximateiy 408 of the phytoplankton standing crop" (M"lllin and Fvans, 1974). Sass densities for abiotic campartments are taken from reported measuremenis of suspended particulates, sediment densitjizs, etc.

b) Transport parameters:

Transport of radicnuclide-carrying material between compartments is described by uptake times and transfer rates for transports involving biotic and abiotjc receiver compartments, respectively. A receiver compartment is a state variable or compartment into which energy or matter is added, while a conor compartment is a state variable or compartment from which energy or matter is removed (Forrester, 1968). uptake times are deiines in the model as the time required, in years, for a given biotic receiver compartment to take up the fraction $\alpha(\alpha=0.50)$ of its biomasc from a giver biotic or abiotic donor 
compartment. Transfer rates are described in tems of ptysical parameters such as distributicn coeficients, exodibility constants, particulate fall velccities, critical shear for ceposition or erosion. probabilities of an erosional or depositional event, characteristic lengths, ano diffusivities.

Future medification of the madel will focus on improving estimates of possjble coses to man as well as possitle environmental effects of radicnuclides in the deep sea. The nadel will evolve through careful parameter study to its simplest possible form, anö all assumptions will be made conservatively with respect to a particular envircrmental effect or aose to man. Moditications will be evaluated accoriing to their significance with respect to the estimation of envirormentel efiects and cose to man.

This initial version of the SDP biotransport model can be vieneo as an ecosystem pump designed expressly for moving radionuclides from sediment, through the water column ano marine biota to man. Operation of this pump is governed by our assumplions regaroing moces of radianuclide uptake and transport in the marine ecosystem.

Ex isting human oosimetric codea will be used to calculate human exposure from released radionuclides fram the df:ep sea. Fisheries consumption data are being compiled to interface with the internal dosimetry moiel(s) in order to calculate cose to man. 


\section{SOP Biology Program}

i) Benthic Biological Studies

The SCP biology program is in the process of characterizing the fauna present in and on the seciment in the central North Pacif ic gyre, incluxing the microbiota, mejofauna, macrofauna anc ahyssopelagic scavengers (Hessler and Jumars, 1974; Hessler and Jumars, 1977; Eurnett, 1977; Hessier et al.. 1978). These studies are tocusing on the potertial of these vârious biotic components to disperse or to concentrate any leaked racioactive wastes.

A characterization of the distribution and density of the r.acro-il.fauna is fairly complete, tut relatively littie is known of the meiofauna and even less about the microbiota. These are impertant because they are the most abundant portions of the infauna anc are at the base of the food web.

of the mobile scavengers jresent focus has been placei on amphipois, since trey are a large component of the abyssal benthic community anc are highly mobile cosmopolitan organisuns. Aspects of their generalized life-style suggest that they may be very important in potenicial mobilization of radionuclices. They appear to feec on the bottom which could allow cirect incorporation of radionuclides present in the sediments, anc their mobility allows direct biological transport. Because amphipods live in the water column, their waste proructs are especially susceptible to physical transport. Thus they may constitute an important early step in a pothway leading ultimately to man.

To date the inaccssibility of the ceep coan environment and the associated pressure and temperature constraints have permitteo only a 
Iimited glimpse into the functional aspects of this ecosystein. an instrument, a free vehicle grab respircmeter (FVGR), has beci: developed to aid in the investigation of the in situ activity rates of the benthic commaity ind'ding oxygen uptake and nutrient exchange (Imith, et al., 1979a). Total axygen uptake and nutrient exchange have been measurec' in siceu in the eastern North Pacific at two stations. Both stations underlie the eutrophic California current systen. There vas no significant difference in total oxygen uptake between stations, but the values were significantly higher than previous measure.rents made at comparable apths from the more olizutrophic nor thest Atlantic ISmith, 1978).

Tire FUiR will also be used to corduct in situ experimests on the effects and fate of injected low-level radiolabelled compounds on transfer rates in the deep-sea benthic cominuity. The cata obtined from these experiments will be of great value in inproving the data base for the SDF foodweb model.

Since nicroorganisms are ubiquitous in ocean water, they offer ideal experimental fossibilities for studying many of the biological phenomena of interest to the subseabed program under the special deep-sea rancitions of extreme food limitation, high pressure and low temperature.

The need for a greater understanding of microbiological proosses in the deep sea is widely recognized. For example, can microbiological activities affect (adversely or favorably) the carister, the waste form or the sediment-radionuclide interactions at planned emplacement depths (30 to 100 meters into the sediments)? 
A substantial effort has been devoted to evaluating the use of the ATP (adenosine triphosphate) methor for assessing the microtial composition of deep-sea seöiments. An important recent fincing has been that the physiological state of deep-sea bacteria is a significant determinant of their ATP content, which wa be increased LE to thirt-3 tiries chat nomally present. by placing the cell at a hydrostatic pressure which is inhibitory to its growth (Yayanos, 1979). This means that the ATP content of a deep-sea sample may cverestimate the number of cells capable of functioning at the depth of the samyle. he have shown that the inhibition of cell oivision by both excossively low as well as excessively high pressures leads to the accuntuietion of AI'F.

Microscopic techniques are preser.tly inacigluate for cetermiring microbial standing stock in the masine enviromert because of their Inability to discinguish IIve from deac bacteria. Alicraciographic and fluorescent labfling techniques have been usec by many laboratories to overcome this difficulty. We are using image analysis instrumentation to develop these fluorescent and sutoraciographic techniques, and are using the techniques to study large numbers of spatially and temporally collectec microbial samples.

In acidition to the indirect methods of microbial detection discusseo above, techniques for the cultivation of deep-sea micrcbes are foing explored. Several deep-sea micrabes rave been successfully isolated (Dietz and Yayanos, 1978; Yayanos, Dietz and Van Boxtel, 1979). One of the many isolates (designated CNPT-3, or iginating in the central lNorth Pacific Ocean) is being studied to determine which of the many cultivation variables are significant. Cultivation at atmospheric 
pressure has been avoided to eliminate or reduce the chance of contamination with shallow water microbes which continuously enter the deep sea.

Spores of bacteria that gron at high temperatures (thermophiles) have been found in deep-sea sediments (Bartholemew and Paik, 1966). Tle ability of these spores to germinate in the presence of heat from emplaced high-level nuclear waste canisters should be cetermined. Eviance to date from the bacterium CNPT-3 and a few other isolates suggests that the deep-sea microbial population will stop functioning above $15 \mathrm{C}$ at 580 bars, indicating that in the $100 \mathrm{C}$ regions surrounding nuclear waste canisters, only spores of thermmphilic bacteria could be viable.

\section{2) Water Colưs Studies}

According to Sinith et al.. (1979a) the open ocean water colimn can be viewed simplistically as a stack of horizontal layers, each inhabited by a disciete faunal assemblage and bounded by the air-water and sediment-water interfaces. This view is complicated by the many animals that transcend these layers wile undergoing vertical migrations (diurnal, seasonal or ontogenetic). The upper layers of the coan ..ave received the most study because of their accessibility and the basic prenise that the whole water column ecosystem is oriven by the food energ! fixed in the surface waters by the autotrophs.

Food energy exchange through the water column can be viewed as either active or passiv.. The passive mode of nutrient transport involves the sinking of particulate organic matter controlled primarily by gravitational forces (Wiebe et al., 1976; Eonjo, 1978). The active 
mode of nutrient transport is the flux mediated by organism transport, and has been equated to a ladier of plankton with overlapping migrational depths of various arimals in a food web down to the abyssal floor (Vinogradov, 1968). Evidence exists on the vertical migration of mesopelingic animals justifying such a bypothesis, but the evideice for active exchange in deeper waters, including the seoiment-water interface, is tenvous. Benthopejagic fistes have been caught in midwater (Hixdrich, 1974; Pearcy, 1976; Nerrett, 1978) giving credence to this exchange. All of tis above work was jerformed with towed nets, and the primary ecological interest was to estimate the downward flux of material.

Recently a free vehicle miobater gill net and baiteó trap-houk array (FWNI) has beer, extensively useci to characterize the abyssopelagic fauna (Smith et al., 1979b). Sampling of the abyssopelagic zone was prompted by limited knowledge of the deep midwater fauna and its significance in the sood energy flow through the open cean ecosystem. Fish and amphipods wich are widely regarded as benthic organisme have been captured with the FWMT up to 730 meters above the abyssal sea floor (Smith et al., 1979b). The presence of these "benthic" animals in the abyssopelagic zone reinforces the idea that there exists a mechanisn for actively transporting material upwards from the sea floor.

A giant conical ret (GCN) is currently being developed. The GaN, which is 100 meters in cianeber and 200 meters long, will be used to help characterize the abyssopelagic fauna by capturing pelagic animals that elude capture with either smaller towed nets or with the FWMT ar ray. 
Estiriates of the population density of deep-sea benthic organisms have been rade using technigues such as grabs, dredges, trawls and camera surveys. However, the densities of the more mobile abyssopelagic animals cannot be accurately determiry.d using these techniques. So, a free vehicle for acoustically assessing abyscopelagic animal population sizes and mobility rates is being developed. This acoustical array will manitcr for long periass of time (months) the movements ot abyssopelag ic populations within a water column $1.9 \mathrm{kilometers}$ in diameter by 100 meters high immediately above the abyssal sediment surface.

These water column studies, as well as the benthic biological studies will provide many of the parameters that are required to exercise the SDP foodweb radionuclide transport model.

\section{3) Radiation Biology Studies}

\section{A. Marine Biota}

Marine organisms have always been exposed to radiation fram natural sources, and estimates of the absorbed dose rate fram natural backgrouno sources have been used to assess the biological significance of any dose rate increment contributed by man's activities. Blaylock and Trabalka (1578) have reviewed the effects of ionizing radiation on aguati= organisms; however, as far as we know, the radiosensitivity of any deep-sea organism has not yet been determined. Until radiation sensitivity studies can be performed on deep-sea organisms, tre data available on the radiosensitivity of shallow-water organisms will be used in estimating any inpacts of released radionuclides on deep-sea organisms. As part of the SDP Eiology frogram an extensive bibliography 
has been prepared on the effects of ionizing radiation on aquatic organisms (Schultz, 1980).

In an effort to acquire data on the radiosensitivity of deep-sea organisins, plan to determine the radiation sensitivity of deep-sea tacteria which can now be cuj'tivateả unóer deep-sea conditions in tive laborciory, and to determine the radiation sensitivity of deep-sea amptipods, sino these can also be recovered alive ano maintainea in the laboratory under deep-sea conditions (Yayanos, 1979!. These initial radiation sensitivity studies will be lethality experiments; however, additional endpoints will be usea in later studies to investigate radiobiological impact on deep-sea organisms. Bacg and Alexander (1961) show that radiosensitivity increases with increasing complexity in living organisms. We will, therofore, compare the raciosensitivity of deep-sea organisms with that of similar shallow-water organisms, in order to determine whether or not marine organisms which occupy equivalent phylogenetic positions are equally raciosensitive or if there are conditions peculiar to the deep sea which may modify (inc.ease or decrease) radiosensitivity. For examp'e, co the pelagic eggs of rattail fishes become more or less radiosensitive because of the vertical ontogenetic migration they andergo which exposes then to pressure changes of several hundred atmospheres and possibly to tempeiuture changes if the eggs penetrate the themocline? This kind of information on radiosensitivity in the deep sea will allow an estinate of the valiajty of using the data obtained from shallow water studies to assess radiobinlogical irpact in the deep sea.

Due to the lack of bicenvironmental data far many radionuclices in 
the marine envirorment, we have constructed three "metabolic equivaiense classes" of radionuclides (plutonium class, strontium class, cesisin class) in order to model the radiological effects of radionuclides in the high-level nuclear waste inventory which may be important contributors to the radiation cose to man and to the environmelt. The assigmment of a racionuelide to a specific class is based upon human dosin:tric considerations. The plutonium class consist:s of ixne-seeking, alpha-enitting radionuclides whose Maximum Permissible Body Burdens (MPBSs) are less than one microcurie. The strontium class consists of beta- or gamma-emitting, bone-seeking radionuclic s with MPBBs greater than one microcurie. The cesium class consists of betau. gama-enitting ruclides which are "soft-tissue" seeke:- The MFBS for radionuclides in this class are greater than ten microcuries.

we are well awars that any grouping of a large number of radionuclides into three metabolic equivalence classes is subject to error because of the wide range of chemical characteristics of those nuclices. Therefore, since we are concerned with raoiation effects we have assumed that since each class contains a radionuclide $\left({ }^{239} \mathrm{Fu},{ }^{90} \mathrm{Sr}\right.$, ${ }^{137} \mathrm{Cs}$ ) for which significant bicenvironmental data are available, 1 rese nuclices can be used to model the other nuclices of the class. Also, since the radiobiological effects of the principal radionuclice of each class are better known than the raoiobiological effects of other members of each class, felt could, in general, conservatively movel the radiobiological effects of each class of radionuclides by using the data available for the princiril nuclide of each class. This scheme will be revised as more oata became available. 
Ultimately a determination of the effects of released radionuclices or a deep-sea community may require an in situ radicbiology experiment.

B. $\underline{\text { an }}$

The basic responsibility for providing guidance in matters of human raaiation safety has been assumea by the International comission on Radiological Protection (ICFP), which was established as the Internatianal X-ray and Radium Protection Commission in 1928.

For the purpose of setting maximum allowable exposure limits, the most sensitive radiation-induced change was assumed to be genetuc damage. It was further assumed that there is rc threshold cose for this effect, that the dose-response curve is linear down to zero dose and that the effect is inopendent of dose rate, that is, only the total cose is of biological significance. Since this means that erery increment of dose increases the likelihood of an adverse effect, and because the benefits to man of the use of nuclear energy are many, the problem is to linit exposure to a level that results in an acceptable risk to the individual and to the population. on the basis of this "acceptable risk concept", the ICRP (1959) defined the maximum permissible dose for an inoividual as "That dose, accumulateo over a long period of time or resulting from a single exposure which, in the rigist. of present knowleoge, carries a negligible probability of severe somatic of genetic injuries; furthermore, it is such a dose that any effects that ensue more frequently are limited to those of a minor nature that kould not be considered unacceptabie by the exposed individual and by competent meoical authorities". The ICRP (1977) later determined that the absorbed dose is insufficient by itself to allow the 
prediction of either the severity or the probability of deleterious effects on health resulting from irradiation under unspecified conditions. Therefore, they introluced a quantity called "dose equivalent" that correlates better with the more important deleterious effects of exposure to radiation, especially with the delayed stochastic effects. Dose equivalent is the absorbed dose weighter by specific modifying factors as defined by the ICRP (1977). Although upper exposure limits have been recommended, the tasic philosophy of radiation protection, which is being followed by the Subseabed Disposal Program, is to keep exposure as low as practicable.

As indicated in the section on Model Development, existing h'man dosimetric oojes coupled with the foodweb transport model will be used to calculate human exposure fram released radionuclides fram the deep sea.

\section{Final Caments}

The task of the SDP biological research program is to provide an adequate lang-term data base to assess the environtmental feasibility of a program to enplace appropriately packaged nuclear waste in ceep-sea sediments. Should subseabeõ emplacement became a reality long-term biological monitoring by sampling bay marine species as indicators of radionuclide migration will be necessary.

Sime the disposal of nuclear waste is an international concern, coperation aung marine biologists of many nations is being encouraged. International cooperation is needed since no single mation should be expected to perform all of the required long-term research. 
Nevertheless, we believe that the tasks of the SDP Biology Program, while formidable, can be accomplished at an acceptable cost over the mext decade or so. 


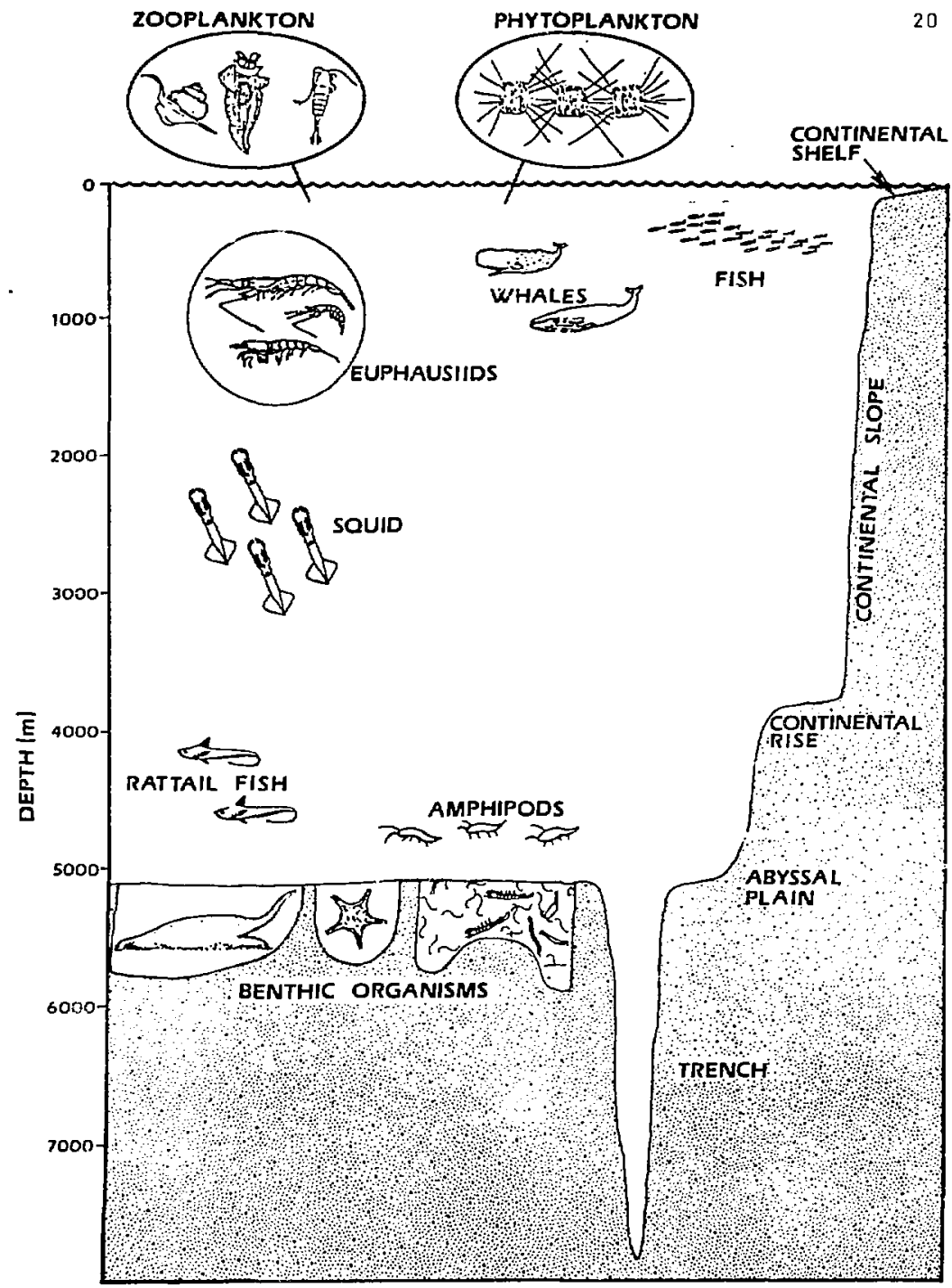

FIGURE 1. REPRESENTATIVE MARINE BIOTA (NOT DRAWN TO SCALE) 


\begin{tabular}{|l}
$\begin{array}{l}\text { WASTE FORM/ } \\
\text { CANISTER }\end{array} \longrightarrow \begin{array}{l}\text { NEAR FIFI.D } \\
\text { MODEL }\end{array} \longrightarrow \begin{array}{l}\text { FAR FIELD } \\
\text { MODEL }\end{array}$ \\
\hline
\end{tabular}

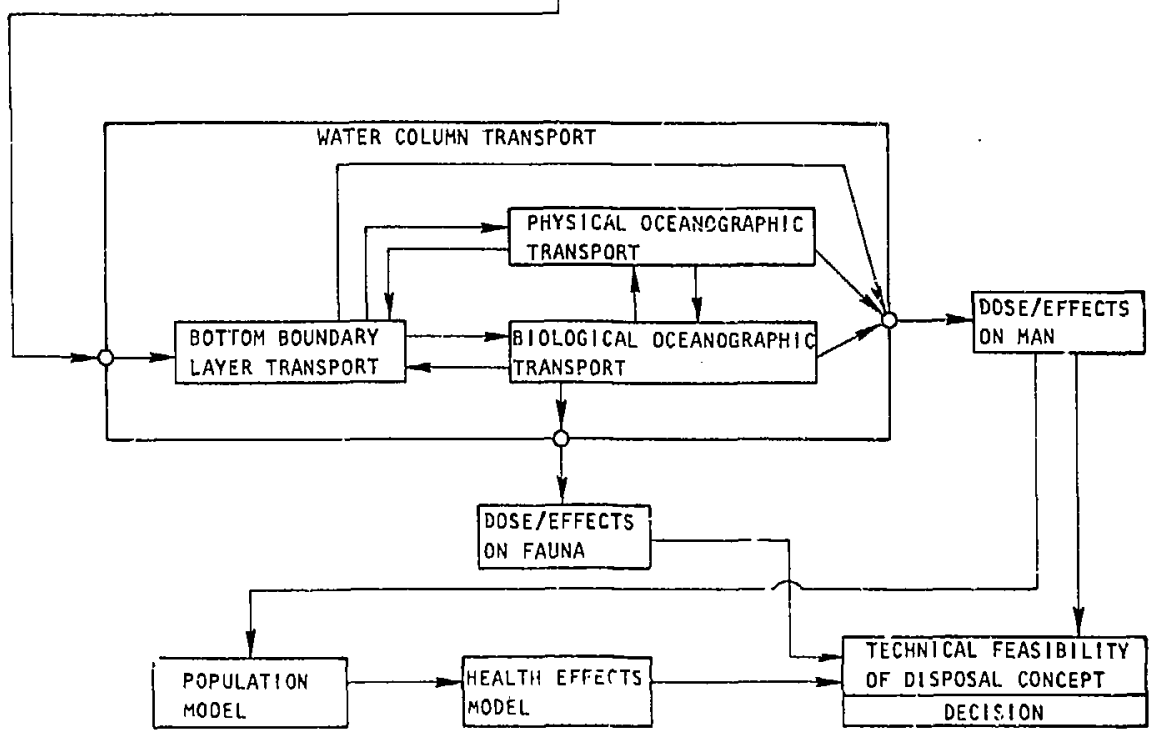

FIGURE 2. ION TRANSPORT ANALYSIS MODEL 


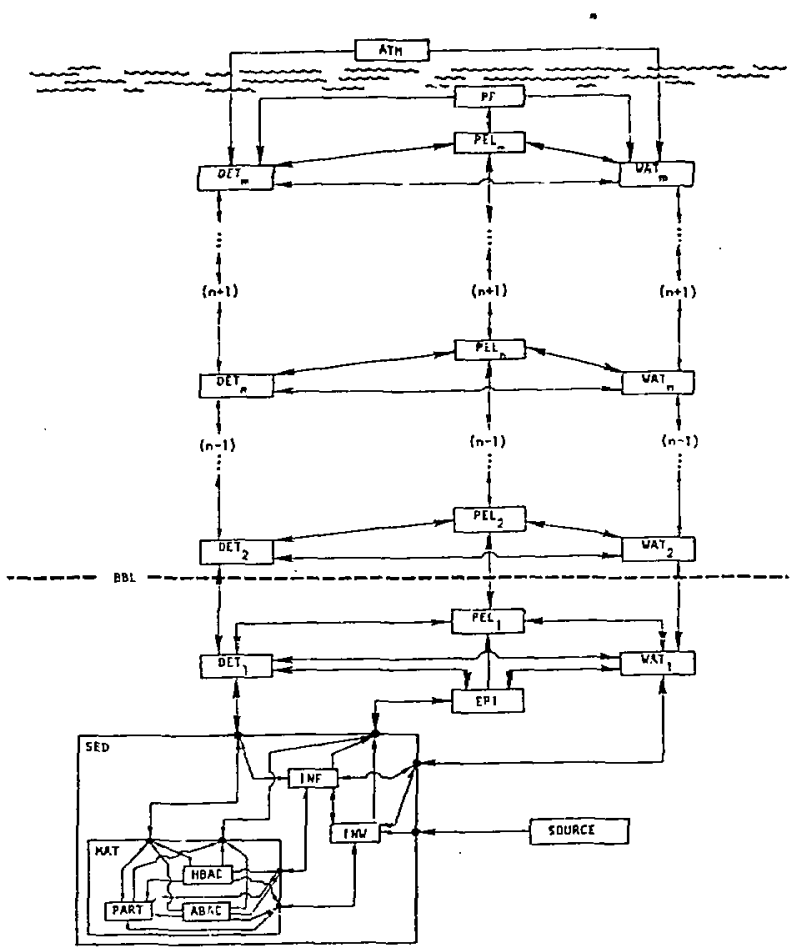

FIGURE 3. MULTICOMPARTMENTAL FOODWEB MODEL 
Definitions of Compartments in Fcodveb Model

ABAC: Autotrophic Bacteria found in the bioturbation zone.

AIM: Atmosphere

DET I: Suspended Particulates. Suspended labile and retractory organic-inorganic complexes (of all sizes) and associated bacteria and microbiota in the first depth interval, autotrophic bacteria.

DET $_{n}$ : Suspended particulates in the $n^{\text {th }}$ depth interval.

EPI: Epibenthic Fauna. Carnivores and deposit-feeding dnimals living on or near the bottan, but never traveling far fram the sediment-water interface.

HBAC: Heterotrophic Bacteria and associated detritus found in the bioturbation zane.

INF: Eukaryotic Benthic Infauna. Deposit feeding (sometimes suspension feeding) and carnivorous animals living beneath the sediment-water interface.

INW: Interstitial Water. Water and dissolved constituents beneath the sediment-water interface.

MAT: Solid Natrix. Labile and refractory organic-inorganic complexes and associated heterotrophic bacteria and microbiota, autotrophic bacteria.

PART: Solio Inorganic Particulates. The remaining solid matris in the bioturbation zone.

PEIL: Pelagic Fauna. zooplankton and nekton in the first depth interval.

PEL $_{n}$ : Pelagic fauna in the $n^{\text {th }}$ depth interval.

PP: Primary Prodursers. Phytoplankton confined to the upper 200 meters of the water columen (euphotic zone).

SED: Sediment Particulates, bulk sediment material incluoiing interstitial waters found within the bioturbation zone.

$\mathrm{WAT}_{1}$ : Water ard dissolved constituents in the first depth interval (above the sediment-water interface).

WAT $_{n}$ : Water and dissolved constituents in the $n^{\text {th }}$ depth interval. 


\section{Feferences}

Anderson, D. R. 1979. Nuclear Waste Disposal in Subseabed Geologic Formations: The Seabed Disposal Progirm. SAND78-2211. Albuquerque: Sandia Laboratories.

Racq, 2. M., and P. Alexander. 1961. Fundamentals of Raciobiology. 2nd ed. Onford: Pergamon Press.

Bartholomew, J. W., and G. Paik. 1966. "Isolation and Icentification of Otligate Thermophilic sporeforming Bacilli from Doan Basin Cores." Journal of Bacteriology, 92, 635.

Elaylock, B. G., and J. R. Trabalka. 1978. "Evaluating the Effects of Ionizing Radiation on Aquatic Organisms." In Advances in Raóiation Biology, Vol. 7. J. T. Lett and H. Adler, eds. New York: Academic prt.SS, E.P. 103-152.

Burnett, B. R. 1977. "Quantitative Sampling of Microbiota of the Deep-Sea Benthos: I. Sampling Techniques and Some Data From the Abyssal Central North Pacific." Deep Sea iesearch, 24, 781-789.

Dayton, P. K., and R. R. Hessler. 1972. "Role of Biological Disturbance in Maintaining Diversity an the Deep Sez." Leep Se? Research, 19, 199-208.

Dietz, A. S., and A. A. Yayanos. 1978. "Silica Gel Media for Isolating anó Studying Bacteria Under Hydrostatic Pressure." Applied Environmental Microbiology, 36, 966-968.

Forrester, J. W. 1968. Principles of Systems. Cambrioge: Wright-Allen Press.

Frankenberg, D., aud K. L. Smith. 1967. "Coprophag: in Marine Animals." Linnology and Coeanography, 12, 443-449.

Haeorich, R. L. 1974. "Pelagic Capture of the Epibenthic Rattail, Coryphaenoides rupestris." Deep Sea Research, 211, 977-979.

bessler, R. R. 1974. "The Structure of Deep Benthic Comunities from Central coanic Waters." In Tte Biology of the oceanic Pacific. Fortland: Oregon State University Press.

Hessler, R. R., and P. A. Jumars, 1374. "Abyssal Comunity Analysis fram Feplicate Box Cores in the Central North Pacific." Deep. Sea Research, 21, 185-209.

-_.-1977. "Abyssal Communities and Radicactive waste Disposal." oceanus, 20, $41-6$. 
- 1979. "The Relation of Benthic Communities to Fadicactive Waste Disposal in the Dep Sea." Ambio, Special Repal t Nmber 6, 93-96.

Hessler, R. R., C. L. Ingram, A. A. Yayanos, and B. R. Burnett. 1976. "Scavenging Amphipods From the Floor of the Philippine Trench." Deep Sea Fesearch, 25, lu29-1047.

Honjo, S. 1978. "Sedimentation of Material in the Sargasso sea at a $5,367 \mathrm{~m}$ Deep Station." Journal of Marine Pesearch, 36, 469-492.

ICRP Publication 1. 1959. Pecomencations of the International Commission on Radiological Protection. Annals of the ICRP. Oxford: Fergamon Press.

ICRP Publication 26. 1977. Pecommendations of the International Comissiar on Radiological Protection. Annals of the ICFP. Oxford: Ferganion Press.

Jackson, D. W. 1979. "Radianuclide Migration Studies." In Subseabed Disposal Program Annual Report, January-December, 1978, Vol. II,

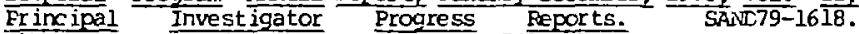
Aíbuquerque: Sandia Laborator ies, p. $721-731$.

Januasch, H. W. 1978. "Experiments in Deep-Sea Aicrobiology." Qgeanus, 2l, 50-57.

Longhurst, A. R. 1976. "Vertical Migration." In The Ecolngy of the Seas, Oushing and Walsh, eds. Philadelphia: h. B. Saunders Co., P. $116-140$.

NCElroy, J. L., and R. E. Burns. 1979. Nuclear waste Nanagement Status and Recent Accomplishments. Report NP-1087. Ralo AI co: Electric Power Fesearch Institute.

Menzies, R. J., R. Y. Ceorge, and G. T. Rowe. 1973. Abyssal Environment and Ecology of the World Qceans. New York: John Wi ley and Sons.

Merrett, N. F. 2978. "On the Identity and Pelagic Docurrence of Larval and Juvenile stages of Rattail Fishes (Family Macrouridae) from $60 \mathrm{~N}, 20 \mathrm{~W}$ and $53 \mathrm{~N}, 20 \mathrm{~W} . "$ Deep Sea Research, 25, 147-160.

Mullin, M. M., and P. M. Evans. 1974. "The Use of a Deep Tank in Plankton Ecology: II. Efficiency of Planktonic Food Chain." Limnologx and coeanography, 23, 1065-1066.

Fearcy, W. G. 1976. "Pelagic Capture of Abyssopelagic Macrourid Fish." Deep Sea Fesearch, 23, 1065-1006.

Russell, F. S. 1976. The Eggs and Planktonic Stages of British Marine Fishes. New York: Acả̉emic Press. 
Sanders, H. L., and R. R. Hessler. 1969. "Ecology of the Deep-Sea Benthos." Scienoe, 163, 1419-1424.

Schultz, v. S. 1980. A Bibliogiaphy cf Marine Radiation Ecology Prepared for the Seabed Program. SAND79-7102. Albuquerque: Sancia Laborator ies.

Smith, K. L., Jr. 1978. "Benthic Community Respiration in the $\mathrm{Ni}$ Atlantic Ocean: In-Situ Measurements fram 40 to $5200 \mathrm{M.}$ " Marire Biology, 47, 337-347.

Smith, K. L. , Jr., G. A. White, and M. B. Laver. 1979a. "Onygen Uptake and Nutrient Exchange of Sediments Measureo In-Situ Lising a Free Vehicle Grab Pespirometer." Deep Sea Pesearch, 26, 337-346.

Smith, K.L., Jr., G. A. White. M. B. Laver, R. R. McConnzughey and J. P. Meador. 1979b. "izee Vehicle Capture of Abyssopelagic Animals." Deep Sea Research, 26, 57-64.

Vinogradov, M. E. 1970. Vertical Distribution of the Coeanic Plankton. /Russian/ Nauka: Israel Program Scienticic Translations.

Wiebe, P. H., S. H. Boyd, and C. Winget. 1976. "Particulate Matter Sinking to the Deep-Sea Floor at $2000 \mathrm{~m}$ in the Torgue of the Ocean, Bahamas, with a Description of a New Sedimentation Trap." Journal of Mar ine Research, 34, 341-354.

Wishner, K. 1977. "An Doean Ecosystem Model." In Seabeo Disposal Program Fart II, January-December 1975. gel M. Taibert, ed. SARD77-1270. Ajbuquerque: Sandia Laboratoriesf pp. 356-364.

Yayanos, A. A. 1978. "Recovery and Maintenance of Live Amphipods at a Pressure of 580 bars From and Doean Depth of 5700 veters." Science, 200, 1056-1059.

- 1979. "Deep Sea Microbial Studies." In Subseabed DisposaI Program Annual Peport, January-December, 1978, VoI. II, Principa? Investigator Progress Beports. SAND79-1618. Albuquerque: Sandia Laborator ies, pp. 873-881.

Yayanos, A. A., A. S. Dietz, and R. Van Baxtel. 1979. "Isolation of Deep-Sea Barophilic Bacterium and some of Its Growth Character istics." Science, 205, 808-810. 